\title{
A Commentary on Peter Buckley's Writings on the Global Factory
}

\author{
Mohammad Yamin
}

\section{Abstract:}

- Peter Buckley's writings on the global factory with specific reference to the paper in this focused issue are discussed in this commentary.

- The commentary points to the possible vulnerabilities of the global factory as an organisational form and links these vulnerabilities to features of the governance regime that supports the global factory.

- The power of the global factory is not purely organisational but also political. The latter is particularly important when considering the impact of the global factory on world welfare and economic development.

Keywords: Global factory $\cdot$ Multinational corporations $\cdot$ Global value chains · The visible hand $\cdot$ Embeddedness $\cdot$ Econcomic development

Received: 02.09.2010 / Revised: 01.11.2010 / Accepted: 25.11.2010 / Published online: 16.03.2011 C) Gabler-Verlag 2011

Prof. M. Yamin $(\bowtie)$

Manchester Business School, University of Manchester, Manchester, United Kingdom e-mail: mo.yamin@mbs.ac.uk

Prof. M. Yamin

Uppsala University, Uppsala, Sweden 


\section{Introduction}

Buckley's recent writings on the Global Factory (Buckley 2009, 2010, 2011; Buckley and Ghauri 2004) represent a sustained intellectual effort aimed at identifying 'the big question' capable of rejuvenating the perceived faltering of the research agenda of international business (Buckley 2002; Buckley and Lessard 2005). Thus the analysis of globalisation with a focus on the dramatic change in the ownership and location strategy of the multinational company (MNC) is seen as providing one such big question. The paper in the present issue focuses specifically on the integration and coordination in the Global Factory stressing the role of the centre as the orchestrator of a complex and extensive network of organizations, working both within and outside the legal boundaries of the lead or nodal firm at the centre of the Global Factory. The Global Factory presents a coherent and well integrated framework. It focuses on the core issue - that is where to locate activities and how to control them. In the process the analysis explicitly and implicitly lays bare the powerful position of the lead firm in the Global Factory.

In my brief comments on the Global factory I focus on two broad issues. The first comment relates to the transformation of the vertical MNCs to the Global Factory. My note raises the question that the power of the global factory has to do mainly with it being more assertive vis-à-vis control over strategy. However it does not necessarily reflect much greater inherent ability at the centre to actually control a far flung network-it has some essentially similar problems - rooted in embeddedness - to that faced by the vertically integrated MNCs. Additionally, it may suffer from inadequate attention to issues relating to long term innovations. My second comment suggests that there is an important political dimension to the power of the Global factory with implications for global welfare and development. Here I briefly link the Global Factory to the value chain literature, which has to-date received surprisingly little attention within the domain of International Business (IB). Surprising, because with maturity, the multidisciplinary IB field seems more parochial and less welcoming to idea-migration from other disciplines (Daft and Lewin 2008).

\section{From the Vertically Integrated MNC to the Global Factory}

The paper on the Global Factory in the present issue focuses to a greater degree (compared to the earlier papers) on the integration and coordination issues. The focus on the integration and coordination issues brings into sharp focus the transformation in the strategy and structure of the MNCs. The traditional preoccupation with the integration vs. responsiveness 'dilemma' was mostly within the context of the vertical, dyadic relationship between the HQ and more or less powerful subsidiaries, whereas the Global Factory now only has a comparatively small 'vertical core' and a much more extensive lateral control over a network of mostly independently owned suppliers and service providers. This transformation is usually explained mostly in terms of developments in ICT advances and a more liberal regulatory environment (Sinkovics and Yamin 2007). However internal dynamics within MNCs have also played a role in the transformation which should not be overlooked. The literature on the embedded multinational (Andersson et al. 2007; Forsgren 
et al. 2005) has shown that in the vertically integrated MNCs control over strategy was in practice a contested phenomenon. Arguably the shift to the Global Factory represents the reassertion of more or less total control by the centre on strategy which is now clearly and exclusively defined in terms of where to locate activities and how to control them. Thus the transformation of vertically integrated MNCs into the Global Factory is at least partly due to the (dysfunctional) internal dynamics of the organisation as perceived by the higher echelon of the MNC (problems such as 'internal monopoly', lack of trust between different divisions and subsidiary opportunism) (Buckley and Ghauri 2004; Rugman and D’Cruz 2003).

In any case, the Global Factory clearly demonstrates the extension of control of large MNCs beyond their own legal boundaries. The key theoretical innovation rests on the combination of markets and hierarchies as instruments for exerting strategic authority within the networked boundaries of the firm whereas the traditional internalisation approach largely rested on a markets-versus-hierarchies perspective. This is significant as the twin globalisation dynamics of technological advance and institutional change have led some analysts to suggest or even claim that the visible hand of corporate coordination is increasingly a 'vanishing' phenomenon. Thus Richard Langlois forcefully asserts: "The visible hand understood as managerial coordination of multiple stages of production within the corporate framework - is fading into a ghostly translucence" (Langlois 2003, p. 352). By contrast, Buckley's analysis is consistent with the proposition that, if anything, the visible hand is becoming stronger. The advances in ICT and production modularity do not necessarily or unambiguously favour markets or relational contracting (Perrow 2009); they can and do also enhance the ability of the visible hand, wielded by MNC headquarters, to better control recalcitrant subsidiaries (Yamin and Sinkovics 2007, 2010). More importantly, the same developments have enabled the Global Factory to effectively coordinate a chain or network of independent but captive suppliers and service providers across many national borders. The Global Factory departs from the rather insular perspective that has dominated the control and coordination issues in the MNCs, namely the focus on the vertical parent subsidiary relationships. In Buckley's analysis of the Global Factory, planning by the lead firm rather than ownership emerges as the key criterion of internalisation. Thus 'the nature of the firm is not a legal entity but as a planning unit' (Buckley 2011, p.4). This has strong echoes of Hymer's analysis of the nature of multinationality as planning capability (Hymer 1970; Yamin and Forsgren 2006) and connects Buckley's analysis to a literature that defines the essence of the large modern corporations in terms of control over strategy and planning and de-emphasises ownership (Cowling and Sugden 1998; Ietto-Gillies 2002).

\section{Some Organisational Vulnerabilities of the Global Factory}

The key to the strategy of the global Factory is the centre's (the HQ of the lead firm) exclusive authority to determine the location of and control over fine-sliced value chain activities. Does this increased authority reflect an underlying enhancement of the centre's control capability? In other words, have HQs become more powerful because the centre is now 'smarter' and can act with greater finesse in protecting and enhancing the viability 
of the Global Factory? Perhaps - Clearly, the control capability of the lead firm in the Global Factory is probably greater than that in the vertically integrated MNC. The more streamlined and focussed structures of activity are probably a relevant factor as are the advances in ICT - although the latter can also facilitate central control in vertically integrated MNCs Nevertheless the proposition that HQs are now smarter should be treated with caution, especially given the increased geographical and (inter)organisational range over which control needs to be exercised by the HQs. There are two reasons for such caution. The first is related, broadly, to the consequences of embeddedness; the second relates to the possible collision between static and dynamic efficiencies.

\section{The Persisting Problem of Embeddedness?}

The demise of the vertically integrated MNEs was in part due to the centre's intolerance of subsidiary embeddedness and the challenges to the HQs authority that it implied (Yamin and Forsgren 2006). However, the problems that embeddedness creates for central control do not necessarily go away in the Global Factory. Embeddedness persists but as an unintended phenomenon and in a different form. The HQs of the lead firm in the Global Factory will clearly exercise thorough due diligence prior to the selection of and agreeing contractual details with its suppliers (this is the essence of Global Factory). But some vulnerability will persist because they are indirectly dependent on the supplier's network. Embeddedness is always a network-dependence phenomenon. The lead firm in the Global Factory may have captive suppliers with an appropriate monitoring process in place (Jean et al. 2010) but the suppliers of the suppliers and their suppliers cannot all be its captives. Risks can emerge from any of the many links in the network and may lie a long way away from the lead firm decision markers' attention locus or indeed be totally unnoticed by anyone in the network until the damage is done (Lynn 2005). As pressures for cost reductions are transmitted through the network, suppliers down towards the bottom of the chain - operating on a shoestring and forced to meet demands for faster and cheaper production may 'cut corners' leading to very negative effects for the whole global production network. Suppliers may be required to meet codes of labour standards and quality control practices stipulated by the lead firms but they may be left with little resources for meaningfully implementing them.

Such risks are, at least partly, endogenous to the system because the governance regime that underpins the Global Factory is deeply committed to shareholder value and an ethos of short-term profit maximisation. It is this focus on short-termism that generates or at least permits the extremes of competitive pressure that could stretch the more vulnerable parts of the network to breaking point. Arguably, the governance regime is concerned, not only with creating value but even more with 'releasing' the value that is perceived to be locked up in vertically integrated but largely decentralised structures. It is an interesting question as to what extent the demise of the vertically integrated MNC has been simply because it has become an 'inefficient' organisational form incongruent with new environmental fundamentals and to what extent it has been a process deliberately engineered by the elite groups at the top of the MNC seeking to reassert strategic authority. 
Operational Efficiency Versus Innovativeness?

The second point is that the Global Factory may be vulnerable to over concentration on operational efficiency. The analysis pays less attention to the organisational requirements for enhancing innovation and creativity though it is clearly recognised that these are vital for the viability of the Global Factory (Buckley 2010, pp.66-67). it is not clear whether the presumption of innovation as a tightly-coupled process of fairly close and extended interchange between $\mathrm{R} \& \mathrm{D}$ and other functions, including production, is accepted by the analysis or not. It may of course be that technological development has enhanced the possibilities of virtual tight-coupling, liberating it from the requirement of physical colocation or proximity. But research on the issue of the impact of outsourcing on innovative performance is, to my knowledge, scant and has not yielded conclusive or consistent results. One recent study points to the likelihood that:

...static gains from outsourced production to lead to dynamic losses due to slower innovation. This stems from the fact that producers partially neglect the impact of their organizational choices on innovation (Naghavi and Ottaviano 2010, p. 1031, my emphasis).

Does the Global Factory entail such 'neglect'? Quite possibly! It is thus significant that, as Buckley notes, there is severe competition within the Global factory with individual units set up to compete for resources. However does such severe competition within the network not reinforce the preference for projects with demonstrable, short term payoff rather the more long-term, more risky but also more creative ones? The study by Lauder et al. (2008) suggests that HRM policies associated with the globalisation of production reinforce the 'neglect' of the impact of organisational choice for innovation. The major preoccupation seems to be win the 'war for talents' that is a focus on the minority of the 'talented' recruits (graduates from elite universities) who are more or less immediately catapulted to positions of leadership in the organisation. The traditional career ladder where managers gain experience and a rounded understanding and thus leadership potential is now increasingly jettisoned. Thus, ironically, as we move further into the so-called knowledge economy only a small minority (and in relative terms a declining one) 'of the knowledge workers has 'permission to think', the majority are being confronted by routinisation’ (Lauder et al. 2008, p. 1).

\section{The Global Factory as a Political Actor: Implications for Economic Development}

Notwithstanding possible organisational vulnerabilities, the Global Factory shows the effectiveness of internalisation 'by other means' (as Clausewitz might have put it). The point is the 'other means 'are usually only available to powerful players. Power in Global Factory stems in part from lead firm's control over enormous productive resources and its organisational capabilities to blend its own technology, marketing knowledge and brand power with resources of its networks to retain market domination (Nolan et al. 2002). But power in the Global Factory is also buttressed by the fact the other erstwhile powerful players - national governments - have, to varying degrees and for a variety of reasons 
decided or have been forced to vacate some of their responsibilities in the realm of the public regulation and mediation between corporate interests, organised labour, consumers and local communities (Perrow 2009). As Sundaram and Black (1992) pointed out some years ago, the distinctive issue in multinational strategy is how to navigate an environmental terrain characterised by the weakness, if not the absence, of a super-structure of external authority. Globalization entails a dramatic extension of this zone of weak external authority, the zone in which there is 'governance without government' (Whitley 2003) and a predominance of private over public regulation (Mayer and Gereffi 2010). Thus, 'markets are globalised by the actions of MNEs (and) their location and ownership strategies' (Buckley and Ghauri 2004, p. 82, my emphasis). Globalisation inevitably sharpens the political dimension of MNCs as they have been and continue to be actively engaged in shaping the institutional environment that is necessary for the exercise of freedom to 'mix and match' locations and controls mechanisms as they see fit, utilising their economic and 'discursive' powers to shape, inter-alia, WTO agreements (TRIMS, TRIPS and GATS) that create and sustain significant asymmetries in terms of the gains between multinational and other stakeholders, notably LDCS (Rodrik 2001; Sell 2003; Wade 2003).

Buckley's analysis is wedded to the notion of Pareto efficiency of the arrangement under the Global Factory (Buckley 2010, 2011) though, on my reading, compared to the earliest statements of internalisation the argument in favour of Pareto efficiency is somewhat circumspect and even half-hearted. This position can be disputed on grounds (noted also by Buckley) of the ubiquity of externalities. Some of the externalities are pretty well central to the operations of the Global Factory. Consider what has been called the dormitory labour regime in factories doing subcontracting jobs for the Global factory in China (Ngai and Smith 2007). The extremely long hours and low wages combined with the family separations characteristics of the dormitory regime can be seen as an externality as some of the costs of reproducing labour are born by the extended family.

However, I would argue that notion of Pareto-efficiency has a paradoxical or even subversive implication: if we accept the possibility of a Pareto-efficient outcome, the challenge - I would even go as far as to say the responsibility - is to examine obstacles preventing a much more equitable sharing of the gains from the Global Factory than the one that currently prevails. Economists may eschew the confounding of efficiency and equality judgements. But if significant inequalities undermine the future sustainability of an essentially workable_- 'efficient' productive arrangement such as the Global Factory then it is not merely good but imperative that we pay particular attention to equity issues. Buckley and Ghauri (2004, p. 92) suggest that many objections to the working of global markets are in effect self-defeating as they can be addressed fully 'only by changes that would dramatically reduce the long term efficiency of the capitalist system'. However, if widespread and extreme inequality undermines the legitimacy and hence the survival of the Global Factory, some sacrifice in terms of loss of efficiency may be necessary. One benefit of the recent financial near catastrophe is that such statements may no longer be regarded as outlandish!

These issues have been explored within the global value chain literature (Bair 2005; Levy 2008) but have been all but ignored within International Business. The global value chain literature has of course had a longer history of explicit engagement with the Global Factory. In fact the very term 'Global Factory' was first used by Fuentes and Ehrenreich 
(1983) to describe a networked production system reflecting deep power asymmetries (Levy 2008, p. 945). Levy argues that the global production chains (or networks) should be conceptualised as a politically contested field in which institutional entrepreneurs (often working through or alongside NGOs) may extract limited gains for disadvantaged groups within the network. These gains are more likely if the lead firm's brand reputation becomes vulnerable to exposures of unethical or socially irresponsible behaviours (Campbell 2007). Levy also observes that these gains are limited and do not necessarily change the fundamental asymmetries in favour of the lead firms (Levy 2008, p. 957). The point is however, that, as a research programme 'capturing the gains' (Barrientos 2009) for those currently excluded or marginalised vis-à-vis the Global Factory has advanced significantly more in the global value chain literature than within International Business which is perhaps too wedded to the efficiency perspective. Arguably Hymer's perspective of 'efficiency contradictions' (Hymer 1970) — recognising that whilst the Global Factory embodies great productive and organisational capability this capability does not necessarily benefit the majority of people that either work for it or are affected by it - provides a more realistic depiction. My reading of Buckley's writings on the Global Factory suggest that he may be moving closer to Hymer's position. Thus, while the analysis certainly entertains the possibility that the Global Factory may improve world welfare, it also contains a clear proposition that the Global Factory constrains economic development (Buckley 2009). Buckley's Global Factory writings can be seen as a suggestion that the IB research agenda is not running out of steam and the injection of insights from neighbouring disciplines may help to keep the engine running.

Acknowledgements: I am grateful to Rudolf Sinkovics for offering a view on Peter Buckley's original submission to this focused issue, related anonymous reviewer correspondence and the invitation to contribute a comment on this debate. Encouraging conversations with him have benefited the development of this paper. I also gratefully acknowledge stimulating discussions arising within the Manchester Business School CIBER seminars (http://www.mbs.ac.uk/ciber), the Manchester 'Capturing the gains' network (http://www.capturingthegains.org/) and the Brooks World Poverty Institute (http://www.bwpi.manchester.ac.uk/).

\section{References}

Andersson, U., Forsgren, M., \& Holm, U. (2007). Balancing subsidiary influence in the federative MNC: A business network view. Journal of International Business Studies, 38(5), 802-818.

Bair, J. (2005). Global capitalism and commodity chains: Looking back, going forward. Competition and Change, 9(2), 153-180.

Barrientos, S. (2009). Capturing the gains research programme, [Webpage]. Manchester: School of Environment and Development, University of Manchester. www.capturingthegains.org/. Accessed 25 Sep 2010.

Buckley, P. J. (2002). Is the international business research agenda running out of steam? Journal of International Business Studies, 33(2), 365-373.

Buckley, P. J. (2009). The impact of the global factory on economic development. Journal of World Business, 44(2), 131-143. 
Buckley, P. J. (2010). The role of headquarters in the global factory. In U. Andersson \& U. Holm (Eds.), Managing the contemporary multinational-The role of headquarters (pp.60-84). Cheltenham: Edward Elgar.

Buckley, P. J. (2011). International integration and coordination in the global factory. Management International Review (this issue).

Buckley, P. J., \& Ghauri, P. N. (2004). Globalisation, economic geography and the strategy of multinational enterprises. Journal of International Business Studies, 35(2), 81-98.

Buckley, P. J., \& Lessard, D. R. (2005). Regaining the edge for international business research. Journal of International Business Studies, 36(6), 595-599.

Campbell, J. L. (2007). Why would corporations behave in socially responsible ways? An institutional theory of corporate social responsibility. Academy of Management Review, 32(3), 946-967.

Cowling, K., \& Sugden, R. (1998). The essence of the modern corporation: Markets, strategic decision-making and the theory of the firm. The Manchester School, 66(1), 59-86.

Daft, R. L., \& Lewin, A. Y. (2008). Rigor and relevance in organization studies: Idea migration and academic journal evolution. Organization Science, 19(1), 177-183.

Forsgren, M., Holm, U., \& Johanson, J. (2005). Managing the embedded multinational: A business network view. Cheltenham: Edward Elgar.

Fuentes, A., \& Ehrenreich, B. (1983). Women in the global factory. Boston: South End Press.

Hymer, S. (1970). The efficiency (contradictions) of multinational corporations. The American Economic Review, 60(2), 441-448.

Ietto-Gillies, G. (2002). Transnational corporations: Fragmentation amidst integration. (Routledge studies in international business and the world economy). London: Routledge.

Jean, R.-J. B., Sinkovics, R. R., \& Cavusgil, S. T. (2010). Enhancing international customer-supplier relationships through IT resources: A study of Taiwanese electronics suppliers. Journal of International Business Studies, 41(7), 1218-1239.

Langlois, R. N. (2003). The vanishing hand: The changing dynamics of industrial capitalism. Industrial and Corporate Change, 12(2), 351-385.

Lauder, H., Brown, P., \& Brown, C. (2008). The consequences of global expansion for knowledge, creativity and communication: An analysis and scenario, [Online]: Beyond Current Horizons. www.beyondcurrenthorizons.org.uk Accessed 20 Nov 2010.

Levy, D. L. (2008). Political contestation in global production networks. Academy of Management Review, 33(4), 943-963.

Lynn, B. C. (2005). End of the line: The rise and coming fall of the global corporation. New York: Doubleday.

Mayer, F., \& Gereffi, G. (2010). Regulation and economic globalization: Prospects and limits of private governance. Business and Politics, 12(3), 1-25.

Naghavi, A., \& Ottaviano, G. I. P. (2010). Outsourcing, complementary innovations, and growth. Industrial and Corporate Change, 19(4), 1009-1035.

Ngai, P., \& Smith, C. (2007). Putting transnational labour process in its place. Work, Employment and Society, 21(1), 27-45.

Nolan, P., Sutherland, D., \& Zhang, J. (2002). The challenge of the global business revolution. Contributions to Political Economy, 21(1), 91-110.

Perrow, C. (2009). Modeling firms in the global economy. Theory and Society, 38(3), 217-243.

Rodrik, D. (2001). Trading in illusions. Foreign Policy, 123, 54-62.

Rugman, A. M., \& D'Cruz, J. R. (2003). Multinationals as flagship firms: Regional business networks. Oxford: Oxford University Press.

Sell, S. K. (2003). Private power, public law: The globalization of intellectual property rights. (Cambridge studies in international relations). Cambridge: Cambridge University Press.

Sinkovics, R. R., \& Yamin, M. (2007). The internet and its paradoxical nature in international business. Critical Perspectives on International Business, 3(4), 288-290. 
Sundaram, A. K., \& Black, J. S. (1992). The environment and internal organization of multinational enterprises. Academy of Management Review, 17(4), 729-757.

Wade, R. H. (2003). What strategies are viable for developing countries today? The world trade organization and the shrinking of 'development space'. Review of International Political Economy, 10(4), 621-644.

Whitley, R. (2003). Changing transnational institutions and the management of international business transactions. In M.-L. Djelic \& S. Quack (Eds.), Globalization and institutions: Redefining the rules of the economic game (pp. 108-133). Cheltenham: Edward Elgar.

Yamin, M., \& Forsgren, M. (2006). Hymer's analysis of the multinational organization: Power retention and the demise of the federative MNE. International Business Review, 15(2), 166-179.

Yamin, M., \& Sinkovics, R. R. (2007). ICT and MNE reorganisation: The paradox of control. Critical Perspectives on International Business, 3(4), 322-336.

Yamin, M., \& Sinkovics, R. R. (2010). ICT deployment and resource-based power in multinational enterprises. Futures, 42(9), 952-959. 